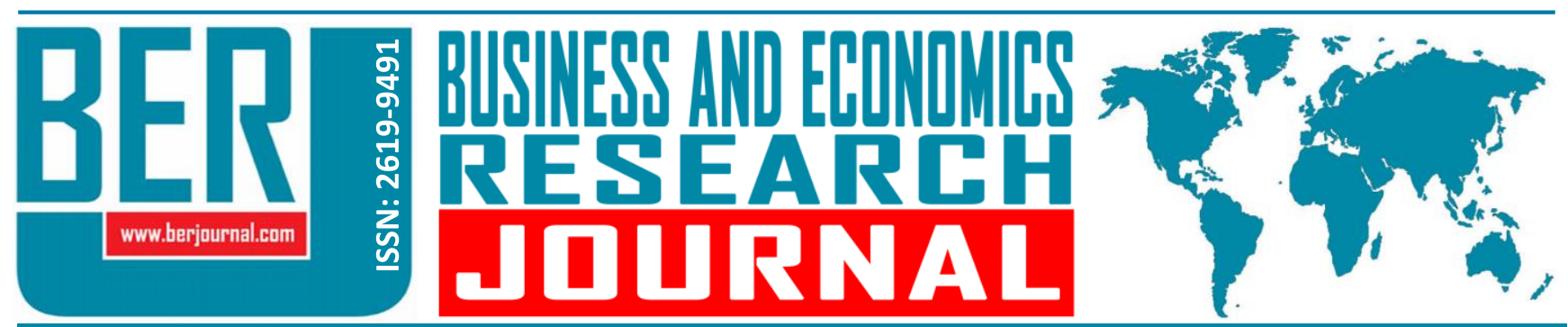

Business and Economics Research Journal Vol. 10, No. 2, 2019, pp. 469-481 doi: 10.20409/berj.2019.180

\section{Sağlık Sektörü Çalışanlarında Tükenmişlik Duygusunun İşten Ayrılma Niyetine Etkisi: Kişi - Örgüt Uyumunun Aracılık Rolü*}

\begin{abstract}
Abdullah Caliskan ${ }^{\mathrm{a}}$, Nazmiye Ulku Pekkan ${ }^{\mathrm{b}}$
Öz: Bu çalışmanın amacı, Sosyal Mübadele Teorisi (Blau, 1964) ile Kişi-Örgüt Uyumu Teorisinden (Tom, 1971) dayanak alarak sağlık sektörü çalışanlarının tükenmişlik duygusunun işten ayrılma niyetine etkisi ve bu etkide kişi-örgüt uyumunun aracılık rolü üstlenip üstlenmediğini tespit etmektir. Bu doğrultuda araştırmanın evrenini, Mersin ili sağlık sektöründe faaliyet gösteren özel hastane çalışanları oluşturmaktadır. Anket formu ile 526 hekim, hemşire ve diğer sağlık çalısanlarından toplanan veriler kullanılarak çalıșmada yer alan değiskenler arasındaki ilișkiler korelasyon, regresyon analizi ile tespit edilmeye çalışılmıştır. Çalışma sonucunda, örneklemi oluşturan sağıı çalışanlarının tükenmişlik duygusuna sahip olduğu ve tükenmişliğin üç alt boyutunun (duygusal tükenme, duyarsızlaşma, kişisel başarıda azalma) işten ayrılma niyeti üzerinde pozitif ve istatistiksel olarak anlamlı ilişkilere sahip olduğu tespit edilmiştir. Araştırmanın bir diğer amacı doğrultusunda kişi-örgüt uyumunun tükenmişlik ve işten ayrılma niyeti ilişkisinde kısmi aracılık etkisine sahip olduğu bulgulanmıştır. Bu sonuçlara göre, bireylerin tükenmişlik düzeyinin artmasının işten ayrılma niyetini artırdığı ve kişi örgüt uyumunun bu ilişkiyi tetikleyici bir etkisi olduğu yönünde bir görüş belirtilmiştir. Çalıșma sonuçları değerlendirilerek gelecekteki uygulayıcılara ve araştırmacılara çeşitli önerilerde bulunulmuştur.
\end{abstract}

\section{The Effect of Burnout in Health Sector Employees on the Turnover Intention: The Mediation Role of Person- Organization Fit}

Anahtar Sözcükler: Tükenmişlik, Kişi-Örgüt Uyumu, İşten Ayrılma Niyeti, Aracılık Etkisi

JEL: M10, M19

\begin{tabular}{|c|c|}
\hline Geliş & : 22 Kasım 2018 \\
\hline Düzeltme & : 08 Ocak 2019 \\
\hline Kabul & : 25 Ocak 2019 \\
\hline Tür & Araştırma \\
\hline
\end{tabular}

Keywords: Burnout, PersonOrganization Fit, Turnover Intention, Mediating Effect

JEL: M10, M19

Received : 22 November 2018

Revised : 08 January 2019

Accepted : 25 January 2019

Type $\quad$ : Research

a Assoc. Prof., PhD., Faculty of Health Sciences, Department of Health Management, Mersin, Turkiye, abdullah.caliskan@toros.edu.tr (ORCID ID: 0000-0001-5746-8550)

b Asst. Prof., PhD., Faculty of Health Sciences, Department of Health Management, Mersin, Turkiye, nazmiye.pekkan@toros.edu.tr (ORCID ID: 0000-0001-7298-0552) 


\section{Giriş}

Sosyal Mübadele Teorisi (Blau, 1964), bireyin beklentileri doğrultusunda zihninde yaptığı ödül-bedel değerlendirmesi sonucunda akılcı bir seçim yapma sürecidir (Emerson, 1976). Bu teorinin örgütlere yansıması, işveren-işgören ilişkilerinde kendini göstermekle birlikte, bireyin örgütten gördüğü ekonomik ve sosyal faydalar bağlamında çabasını arttırıp azaltması şeklinde olmaktadır (Cropanzano ve Mitchell, 2005). Kişi- Örgüt Uyumu Teorisi (Tom, 1971) ise, bireyin ve örgütün karşılıklı bir şekilde beklentilerinin karşılandığı ve her iki tarafın da benzer karakteristik özelliklere sahip oldukları durumlarda ortaya çıkan uyum halidir (Çalışkan, 2017). Bu teoriye göre, bireylerin örgütleriyle uyum içerisinde olmaları tatminsizlik, stres, tükenmişlik ve işten ayrılma niyeti gibi davranışlar göstermelerini azaltmaktadır (Posner, 1992; Cable ve Judge, 1994).

Yaşamın herhangi bir döneminde ve herhangi bir alanında (iş, özel, sosyal yaşam vb.) yaşanabilecek bir durum olarak karşımıza çıkan tükenmişlik duygusu, duygusal açıdan tükenme, duygudan yoksun olma durumunu ifade eden duyarsızlaşma ile kişisel başarıda yetersizlik hissini ifade etmektedir. İşten ayrılma niyeti, bireylerin işlerinden duydukları tatminsizlik sebebiyle çalışma isteklerini kaybetme niyetini; kişi-örgüt uyumu ise, birey ve örgüt ihtiyaçlarının karşılıklı bir biçimde karşılanması sonucu oluşan uyumu ifade etmektedir.

Illgili literatürde, tükenmişlik ve işten ayrılma niyetinin bir arada incelendiği, kişi-örgüt uyumu ile işten ayrılma niyetinin birlikte ele alındığı çeşitli çalışmalara rastlamak mümkündür. Kuramsal bilgiler ve görgül araştırmalar bu üç değişkenin birbiri ile ilişkilerini ortaya koymaktadır. Bu çalışmayı daha önce yapılmış çalışmalardan ayıran özellik, tükenmişlik ve işten ayrılma niyeti ilişkisinde kişi-örgüt uyumunun aracılık etkisinin olduğunun öne sürülmesi olarak düşünülmektedir. Bu çalışma ile kurgulanan araştırma sorusu şu şekilde ifade edilebilir; Tükenmişlik ile işten ayrılma niyeti ilişkisinde kişi-örgüt uyumunun aracılık etkisi var midır?

\section{Kavramsal Çerçeve}

\subsection{Tükenmişlik}

Tükenmişlik, bireyin uğraş verdiği işten ve amacından uzaklaşması ve dolayısıyla etkileşim içerisinde olduğu insanlarla artık ilgilenememesi şeklinde tanımlanmaktadır. Maslach tükenmişliği alan yazında en çok kabul gördüğü haline geliştirerek; duygusal tükenme, duyarsızlaşma ve kişisel başarıda azalma olarak üç ayrı boyutta ele almıştır (Maslach vd., 2001; Altay vd., 2010).

Yapılan çalışmalar göstermektedir ki; tükenmişlik olgusu, hemşirelik, hasta ve yaşlı bakıcılığı, doktorluk, öğretmenlik ve polislik gibi insanlarla sürekli iletişim ve etkileşim içinde olmak durumunda kalan meslek gruplarında daha fazla görülmektedir (Ergin 1992; Ardıç 2009). Söz konusu bu olumsuz durumun da bu meslek grubundaki bireyler üzerinde fiziksel ve ruhsal pek çok açıdan farklı sorunları ortaya çıkarttığı savunulmaktadır (Maslach vd., 2001; Haran vd., 1998; Özgüven ve Haran, 2000).

Sağlık alanında çalışan bireylerin yaşadığı tükenmeyi ifade etmek için tükenmişlik kavramı ilk kez Freudenberger tarafından literatüre kazandırılmıştır. Sonraki dönemlerde ise tükenmişlik, Maslach ve Jackson tarafından, fiziksel tükenme, kronik yorgunluk, çaresizlik ve umutsuzluk hisleri gibi hem mesleğe hem genel yaşama hem de diğer insanlara yönelik olumsuz tutumlarla kendini gösteren, fiziksel ve mental bir tükenme durumu olarak tanımlanmıştır (Çam, 1998).

Tükenmişlik, ilgili literatürde en sık kullanılan hali ile, "duygusal tükenme, duyarsızlaşma ve kişisel başarıda azalma" olmak üzere üç alt boyutta ifade bulmuştur (Maslach vd., 1986).

Duygusal Tükenme alt boyutu, bireye gereğinden fazla yüklenilmiş olması ile bireyin duygusal kaynaklarının tükenmesini ifade etmektedir.

Duyarsızlaşma alt boyutu, bireyin işi dolayısıyla hizmet sunduğu insanlara karşı sert ve duygudan yoksun olarak ifade edilebilecek düzeyde olumsuz davranışlarını içermektedir. Duyarsızlaşma yaşayan kişi, diğer insanlara saygılı ve nazik davranmayı reddedebilir, onların istek ve taleplerini görmezden gelebilir. Bu 
duyarsızlaşma diğer insanlara karşı aldırmazlık, nefret hissetme ve onlardan uzaklaşmayı da içeren olumsuz davranışlar, insancıl olmama ile kendini gösterir (Maslach, 1976; Garden, 1987).

Kişisel Başarıda Azalma alt boyutu ise; bireyin yaptığı işte kendisini yeterli ve başarılı hissetmemesini ifade etmektedir. Bu boyutta birey kendisine ilişkin değerlendirmelerde bulunurken olumsuzluk hisseder; yaptığı işte ilerleme kaydedemediğini, hatta gerilediğini, harcadığı çabanın bir işe yaramadığını ve dolayısıyla çevresinde bir fark yaratamadığını düşünür (Maslach ve Jackson, 1981).

\subsection{Kişi- Örgüt Uyumu}

Kişi-örgüt uyumu, örgütsel davranış çalışmalarında pek çok farklı kavramla ilişkilendirilerek incelenen bir kavram olarak karşımıza çıkmaktadır. Bu ilginin en önemli sebeplerinden biri hiç kuşkusuz sosyal bir varlık olan birey ile etkileşim içinde olduğu çalışma ortamının ilişki yönetiminin iki önemli tarafı olmasıdır.

Değişimin kaçınılmaz olduğu ve her geçen gün artarak her alanda kendini gösteriyor olması gerçeği, uyum konusunu daha da önemli bir hale getirmektedir. Örgütsel anlamda uyum daha çok çevre ile uyum olarak anlaşılırken, bireysel anlamda uyumun ise, hem çevreye hem örgüte hem de diğer faktörlere uyum olarak gündeme geldiği görülmektedir (Turunç, 2015).

Kişi-örgüt uyumu, kişi-çevre uyumunun bir alt boyutu (Vilela, Varela ve Ferrin, 2008), kişi-iş uyumunun ise genişletilmiş hali (Akbaş, 2011) olarak literatüre kazandırılmıştır. Kişi-örgüt uyumu teorisine göre, kişiler yer aldıkları örgütlerle aralarında çeşitli açılardan bir uyum hali yakaladıklarında bu olumlu durumu davranış ve tutumlarına yansıtmaktadır (Billsberry, Ambrosini, Moss-Jones ve Marsh, 2005). Başka bir tanıma göre, kişi-örgüt uyumu, bireyin çalıştı̆̆ı örgütte algıladığı uyumun derecesidir. Diğer bir ifade ile kişi-örgüt uyumu, bireyin kişisel değerleri ve özelliklerinin örgüt kültürü ile ne kadar uyumlu olduğuna dair öznel bir yaklaşımını ifade etmektedir (Cable ve DeRue, 2002; Cable ve Parsons, 2001). Örgütte bu uyumu algılayan çalışanlar, daha fazla çaba sarf ederek organizasyonel etkinliklere gönüllü katılım göstermekte, iş arkadaşlarına daha çok yardım etmekte ve onları destekleme eğiliminde bulunmaktadır (Wei, 2012).

\section{3. İșten Ayrılma Niyeti}

İşten ayrılma niyeti, bireylerin çalıştıkları örgütten ayrılmak için yaptıkları planları ya da isteklerini ifade etmek için kullanılan bir kavramdır (Cuskelly ve Boag, 2001). Sousa-Poza ve Henneberger (2002) işten ayrılma niyetini, bireyin çalışmakta olduğu işinden belirli bir zaman içinde istifa etme olasılığı olarak tanımlamaktadır. Bir başka tanımda işten ayrılma niyeti, çalışanların örgüt içerisinde bilinçli bir şekilde düşük performans göstermeleri ve örgütü terk etme eğilimleri olarak tanımlanmıştır (Tett ve Meyer, 1993). Lambert (2006)' in tanımına göre işten ayrılma niyeti, bilişsel bir süreç olarak düşünme, planlama ve istemeden oluşmaktadır. Takawira, Coetzee ve Schreuder (2014) işten ayrılma niyetini, bireyin çalıştığı örgütü terk etme ve başka bir örgütte iş arama fikrine sahip olma durumu olarak tanımlamaktadır. Benzer bir tanımda işten ayrılma niyeti Thakre (2015) tarafından, bir örgüt içerisinde çalışan bireylerin gönüllü olarak yaptıkları işi bırakma eylemi ve yeni bir iş bulma davranışı sergilemeleri olarak tanımlanmıştır.

İşten ayrılma niyeti, bir örgütte çalışan bireyin mevcut işindeki tatminsizliğinin önemli bir göstergesidir. Ancak, gerçek işten ayrılma davranışının tespit edilmesi aslında zor bir durumdur. Bunun sebebi olarak da anket yolu ile bireylerden toplanan verilerin bireyin gerçek niyetini tam olarak yansıtmaması ve çalışanların işi bırakma eylemlerini izlemenin zor olması olarak gösterilmektedir (Johnsrud ve Rosser, 2002). Buna rağmen Meisler (2013), işten ayrılma niyetinin işi bırakmayı düşünmek ve yeni iş teklifleri ile ilgilenmek olmak üzere iki boyutta ölçülebileceğini ifade etmektedir.

\section{Teori Ve Hipotezler}

Sağlık sektöründe çalışanların tükenmişlik algısı ve kişi-örgüt uyumunun çalışanların işten ayrılma niyetine olan etkisi ve söz konusu bu etkide kişi-örgüt uyumunun aracılık rolünü tespit etmek üzere kurgulanan bu çalışmada ilk olarak literatür incelenerek teorik çerçeve ortaya konulmuştur. Bu kapsamda girdi değişken olarak ele alınan tükenmişlik algısı ve kişi-örgüt uyumu ile çıktı değişken olan çalışanların işten 
ayrılma niyeti arasındaki ilişkiler araştırılmış ve ardından söz konusu bu ilişkilerin etkisinde kişi-örgüt uyumunun rolü ele alınarak hipotezler oluşturulmuştur.

\subsection{Tükenmişlik ve Kişi-Örgüt Uyumu ilişkisi}

Tükenmişlik kavramı ile ilgili alan yazın incelendiğinde, tükenmişliğin bireysel ve örgütsel pek çok faktörün (mobbing, çalışma koşulları, stres, düşük öz-yeterlilik, kişilik özellikleri, örgütsel bağlılık, iş tatmini, örgütsel adalet vb.) bir sonucu olabileceği (Storm ve Rothmann, 2003; Uluköy, 2014; Aghdasi, 2014; Tosun ve Ulusoy, 2017) ve bunun yanı sıra bu olumsuz duygunun da birçok olumsuz duruma (işten ayrılma niyeti, tatminsizlik, örgütsel bağlılıkta azalma, sessizlik, sinizm vb.) öncül olabileceği araştırma sonuçlarıyla desteklenmektedir (Simha vd., 2014).

Babakuş, Yavaş ve Ashill (2011), müşteri odaklılık ve hizmetkâr liderliğin hizmet sektöründe çalışan kişilerin tükenmişlik düzeylerini ne oranda etkilediğini tespit etmek üzere yapmış oldukları çalışmada, kişi-iş uyumunun bu ilişkideki aracııı etkisini de incelemişlerdir. Bu amaçla Yeni Zelanda'daki 530 banka çalışanı üzerinde bir uygulama gerçekleştirmişlerdir. Çalışma sonucunda, müşteri odaklııı ve hizmetkâr liderliğin tükenmişliği önemli oranda azalttığı ve bu ilişkide kişi-ş uyumunun aracılık etkisine sahip olduğu tespit edilmiştir.

Dursun, Kaya ve İştar (2015) yapmış oldukları çalışmada, kişilik-iş uyumu ve iş-yaşam doyumunun duygusal tükenmişlik üzerine etkisini incelemek üzere muhasebeci olarak çalışan 154 kişi üzerinde uygulamalı bir araştırma gerçekleştirmiştir. Çalışma sonucunda, kişilikleri ile meslekleri uyumlu olan bireylerin daha az duygusal tükenmişlik yaşadıkları tespit edilmiştir.

Tong, Wang ve Peng (2015), kişi-çevre uyumsuzluğundan yola çıkarak iş tükenmişliğini tespit etmek amacıyla 199 çalışan üzerinde uygulamalı bir araştırma gerçekleştirmişlerdir. Çalışma sonucunda, kişi-örgüt uyumu ve kişi-iş uyumunun tükenmişliğin üç alt boyutu olan duygusal tükenme, duyarsızlaşma ve kişisel başarıda azalma ile ilişkili olduğu tespit edilmiştir. Araştırmacılar çalışma sonuçları doğrultusunda, hem bireylere hem de örgütlere yönelik çeşitli öneriler sunmuşlardır. Bunlardan biri, çalışanların kendilerine uygun işleri tercih etmelerinin örgüte uyumu kolaylaştırıcı etkisi hem de çalışanların ruh sağığını korumada etkili olacağı yönündedir. Diğer öneri ise, kişi-örgüt uyumu gözetilerek yapılan personel seçiminin örgüt maliyetlerini azaltacağı yönündedir.

Tükenmişlik duygusu ile kişi-örgüt uyumu arasındaki ilişkiyi irdeleyen çalışmalar ve kuramsal bilgilerden yola çıkarak tükenmişlik duygusunun alt boyutlarının kişi-örgüt uyumuna etkisini belirlemek amacıyla kurgulanmış olan hipotezler aşağıda sunulmuştur.

Hipotez 1: Duygusal tükenme, kişi-örgüt uyumunu negatif ve anlamlı olarak etkiler.

Hipotez 2: Duyarsızlaşma, kişi-örgüt uyumunu negatif ve anlamlı olarak etkiler.

Hipotez 3: Kişisel başarıda azalma, kişi-örgüt uyumunu negatif ve anlamlı olarak etkiler.

\subsection{Tükenmişlik ve İşten Ayrılma Niyeti iliş̧sisi}

Tükenmişlik duygusu, hangi sektörde faaliyet gösterdiği fark etmeksizin tüm örgüt çalışanlarında görülebilmektedir. Ancak özellikle hizmet sektöründe faaliyet gösteren örgütlerde çalışanlar açısından daha da önemli bir sorun olarak ortaya çıkmaktadır. Çalışanlarda tükenmişlik duygusunun artış göstermesi, onlar açısından iş yaşamlarını olumsuz etkileyecek fiziksel ve mental açıdan istenmedik sonuçlar doğurmaktadır. Tükenmişliğin fiziksel sonuçları; yorgunluk, bitkinlik, uyku bozuklukları, baş ağrısı, uyuşukluk, solunum güçlüğü, deri şikâyetleri, sindirim güçlükleri şeklinde kendini gösterirken; mental olarak sonuçları; duygusal tükenme, çabuk öfkelenme, içe kapanma, negatif duygular, alınganlık vb. duygu odaklı olarak ortaya çıkmaktadır. Tükenmişlik duygusu örgüt içerisinde ise; hizmet kalitesinde düşme, işe gelmeme isteği, işten ayrılma isteği, iş kazaları, performansta düşüş olarak zararlı sonuçlarla ortaya çıkmaktadır (Aslan, 2014). Görüldüğü üzere hem bireysel hem de örgütsel pek çok olumsuzluğu beraberinde getiren tükenmişlik duygusunun yarattığı olumsuz sonuçlardan biri çalışmaya konu olan işten ayrılma niyetidir. 
Tükenmişlik duygusu ile işten ayrılma niyeti arasındaki ilişkiyi irdeleyen çalışmalar bu iki değişken arasında pozitif ilişkiler olduğunu ve tükenmişlik duygusunun işten ayrılma niyetini arttırdığını bulgulamıştır (Onay ve Kılcı, 2011; Ismail, 2015; Azharudeen ve Andrew, 2018; Santoso vd., 2018).

Söz konusu araştırma sonuçlarından ve kuramsal bilgilerden yola çıkarak tükenmişlik duygusunun alt boyutlarının çalışanların işten ayrıma niyetine etkisini belirlemek amacıyla kurgulanmış olan hipotezler aşağıda sunulmuştur.

Hipotez 4: Duygusal tükenme, çalışanların işten ayrılma niyetini pozitif ve anlamlı olarak etkiler.

Hipotez 5: Duyarsızlaşma, çalışanların işten ayrılma niyetini pozitif ve anlamlı olarak etkiler.

Hipotez 6: Kişisel başarıda azalma, çalışanların işten ayrılma niyetini pozitif ve anlamlı olarak etkiler.

\subsection{Kişi-Örgüt Uyumu ve İşten Ayrılma Niyeti ilişkisi}

Bireylerin yaşamının büyük bir bölümünü oluşturması bakımından iş hayatında yaşanan büyük küçük tüm gelişmeler birey üzerinde doğrudan etki yaratmaktadır.

Bireyin kişiliğini oluşturan, davranışlarının temelinde yer alan, kendini ve başkalarını tanımaya yardım eden bir kavram olan değerler, birey için neyin iyi neyin kötü; neyin kabul edilebilir veya neyin kabul edilemez olduğunu anlatan ölçütlerdir. Bu açıdan bakıldığında bireyin değer tanımı bireyin hayatına dair önemli ipuçları sunmaktadır. Örgütsel açıdan değerler ise, örgüt için neyin istenen ya da istenmeyen davranış olduğunu gösteren ilkelerdir. Öyleyse birey ve örgütün ayrılmaz bir bütün olduğu ve karşılıklı olarak sürekli bir etkileşim ve iletişim gerekliliği birey ve örgüt değerlerinin uyumunu daha önemli bir hale getirmektedir.

Kişi-örgüt uyumunun örgütsel çıktılarına yönelik yapılan çalışmalar, söz konusu kavramın örgütsel bağlılık, iş tatmini (Sökmen ve Bıyık, 2016), işte mutluluk (Sousa ve Porto, 2015), örgütsel özdeşleşme, örgütsel vatandaşlık (Özçelik ve Afacan Fındıklı, 2014), öğrenme (Makraiova vd., 2014) ve performans (Farooqui ve Nagendra, 2014; Çetinkaya ve Kurnaz, 2017) gibi çok çeşitli değişkenlerle aralarında pozitif etkilere sahip olduğunu; sinizm, işten ayrılma niyeti (Behram ve Dinç, 2014; Abzari vd., 2015; Nuansa vd., 2018), tükenmişlik, örgütsel sessizlik, stres (Deniz vd., 2015) gibi değişkenler üzerinde ise negatif etkilere sahip olduğunu göstermektedir.

Kişi-örgüt uyumu ile işten ayrılma niyeti arasındaki ilişkiyi irdeleyen çalışmalar ve kuramsal bilgilerden yola çıkarak kişi-örgüt uyumunun çalışanların işten ayrılma niyetine etkisini belirlemek amacıyla kurgulanmış olan hipotezler aşağıda sunulmuştur.

Hipotez 7: Kişi-örgüt uyumu, çalışanların işten ayrılma niyetini negatif ve anlamlı olarak etkiler.

$\mathrm{Bu}$ kapsamda yapılandırılan araştırma modeli Şekil 1'de sunulmuştur. Araştırma modelinin gösterildiği şekil üzerinde karmaşıklık yaratabileceği düşüncesi ile aracılık hipotezleri şekil üzerinde gösterilememiştir.

Yapılan araştırmalardan elde edilen bulgulardan, tükenmişlik duygusunun işten ayrılma niyetine etkisinde kişi-örgüt uyumunun aracılık rolü olabileceği düşünülmektedir. Literatürde işletmelerde tükenmişlik duygusunun çalışanların işten ayrılma niyetine etkisinde kişi-örgüt uyumunun aracılık rolünü inceleyen bir araştırmaya rastlanmamıştır. Bu ihtiyaçtan yola çıkılarak tükenmişlik duygusunun işten ayrılma niyetine etkisinde kişi-örgüt uyumunun aracılık rolünü araştırmak üzere aşağıdaki hipotezler oluşturulmuştur.

Hipotez 8: Duygusal tükenme düzeyinin işten ayrılma niyetine etkisinde kişi-örgüt uyumunun aracılık rolü vardır.

Hipotez 9: Duyarsızlaşma düzeyinin işten ayrılma niyetine etkisinde kişi-örgüt uyumunun aracılık rolü vardır.

Hipotez 10: Kişisel başarıda azalma düzeyinin işten ayrılma niyetine etkisinde kişi-örgüt uyumunun aracılık rolü vardır. 
Şekil 1. Araştırma Modeli ve Hipotezler

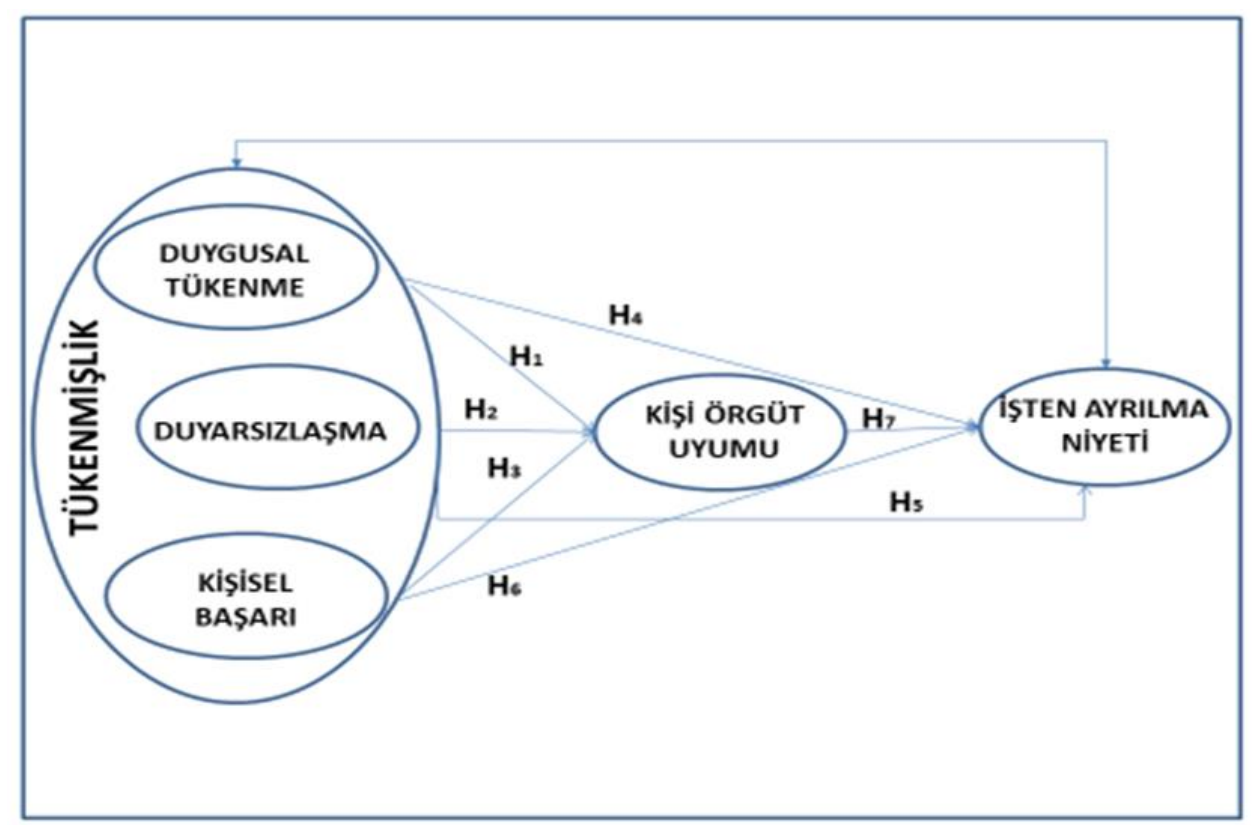

\section{Araştırmanın Yöntemi}

\section{1. Örneklem}

Sağlık sektörü çalışanlarının tükenmişlik düzeylerinin işten ayrılma niyetine etkisini incelemeye ve kişi-örgüt uyumunun aracılık rolünü belirlemeye yönelik olan bu araştırma kapsamında öncelikle örneklem ve ölçeklere ilişkin bilgilere yer verilmiştir. Ardından örneklemden elde edilen veriler ışığında oluşturulan modele ilişkin analizler yapılmıştır. Bu kapsamda öncelikle her bir değişkenin doğrulayıcı faktör analizi yapılmış ardından değişkenler arası korelasyonlar tespit edilmiştir. Baron ve Kenny (1986) tarafından önerilen üç aşamalı hiyerarşik regresyon analizi ile hipotezler ve aracılık etkileri test edilmiştir. Aracılık bulguları Sobel testi ile sınanmıştır.

Araştırma evrenini, Mersin ilinde faaliyet gösteren özel hastane çalışanı olan hekimler, hemşireler ve diğer sağlık çalışanları oluşturmaktadır. Bu evrende yaklaşık 6000 kişi çalışmaktadır. Ana kütleden \%95 güvenilirlik sınırları içerisinde \%5'lik bir hata payı dikkate alınarak örneklem büyüklüğü 361 kişi olarak hesap edilmiştir (Sekaran, 1992). Bu kapsamda kolayda örnekleme yöntemiyle, tesadüfî olarak seçilen özel hastanelerden toplam 1000 kişiye anket uygulaması yapılması planlanmıştır. Anketlerden 537' si geri dönmüş, 526'sı analiz yapmak için uygun bulunmuştur.

Örnekleme ilişkin demografik veriler Tablo 1' de sunulmuştur:

Tablo 1. Çalışanların Demografik Özellikleri

\begin{tabular}{|c|c|c|c|c|c|c|c|c|c|c|c|}
\hline & $\mathbf{F}$ & $\%$ & & $F$ & $\%$ & & $\mathbf{F}$ & $\%$ & & $\mathbf{F}$ & $\%$ \\
\hline \multicolumn{3}{|c|}{ Çalışma Süresi } & \multicolumn{3}{|l|}{$\underline{\text { Yass }}$} & \multicolumn{3}{|c|}{ Cinsiyet } & Ĕğitim & & \\
\hline $1-5 \mathrm{yll}$ & 226 & 42,96 & $22-25$ & 143 & 27 & Erkek & 239 & 45,43 & Lise & 113 & 21,48 \\
\hline 6-10 yıl & 158 & 30,03 & $26-30$ & 211 & 40 & Kadın & 287 & 54,56 & Lisans & 198 & 37,64 \\
\hline 11-15 yıl & 98 & 18,63 & $31-40$ & 101 & 19 & \multicolumn{3}{|c|}{ Medeni Hal } & Y.Lisans & 103 & 19,58 \\
\hline 15 yıl ve & 44 & 08,36 & 40 üstü & 71 & 14 & Evli & 251 & 47,71 & Doktora & 112 & 21,29 \\
\hline \multicolumn{6}{|l|}{  } & Bekar & 275 & 52,28 & & & \\
\hline
\end{tabular}




\section{2. Ölçekler}

Sağlık çalışanlarının tükenmişlik düzeylerini belirlemek için Maslach ve Jackson (1981) tarafından geliştirilen, Türkçe geçerlemesi Ergin (1992) tarafından yapılan 3 boyuttan oluşan 22 maddelik Maslach Tükenmişlik Envanteri kullanılmıştır. Maslach Tükenmişlik Envanterinin birinci alt ölçeği 9 maddeden oluşan "Duygusal Tükenme" (DT), ikincisi 5 maddeden oluşan "Duyarsızlaşma" (DYR) ve üçüncüsü de 8 maddeden oluşan "Kişisel Başarı" (KB) alt ölçeğidir. Ölçekte cevaplar 5'li Likert ölçeği ile alınmıştır (1=Kesinlikle katılmıyorum, 5=Kesinlikle katılıyorum).

İşletmelerde kişi-örgüt uyumu düzeyini belirlemek üzere, Netemeyer ve arkadaşları (1997) tarafından geliştirilen, Vilela ve arkadaşları tarafından kullanılan ve Türkçe geçerlemesi Turunç ve Çelik (2012) tarafından yapılan 4 maddeli ölçek kullanılmıştır. Ölçekte cevaplar 5'li likert ölçeği ile alınmıştır (1=Kesinlikle katılmıyorum, 5=Kesinlikle katılıyorum).

Çalışanların işten ayrılma niyetinin ölçülmesinde Scott ve arkadaşları (1999) tarafından geliştirilen ve Türkçe uyarlaması Aylan (2012) tarafından yapılan 5 ifadeden oluşan ölçek kullanılmıştır. Ölçümler $5^{\prime}$ li Likert tipindedir.

\section{Bulgular}

\subsection{Doğrulayıcı Faktör Analizi}

Ölçeklerin faktör yapılarının sağlamasını yapmak üzere gerçekleştirilen doğrulayıcı faktör analizine ilişkin bulgular aşağıda Tablo 2'de gösterilmiştir.

Tablo 2. Doğrulayııı Faktör Analizi Sonucunda Ölçeklerin Uyum İyiliği Değerleri

\begin{tabular}{|l|c|c|c|c|c|c|c|c|c|}
\hline Değişkenler & $\mathbf{X}^{\mathbf{2}}$ & $\mathbf{d f}$ & $\begin{array}{c}\text { CMIN/DF } \\
\mathbf{5}\end{array}$ & $\begin{array}{c}\text { GFI } \\
\mathbf{2 . 8 5}\end{array}$ & $\begin{array}{c}\text { AGFI } \\
\mathbf{2 . 8 0}\end{array}$ & $\begin{array}{c}\text { CFI } \\
\mathbf{2 . 9 0}\end{array}$ & $\begin{array}{c}\text { NFI } \\
\mathbf{2 . 9 0}\end{array}$ & $\begin{array}{c}\text { TLI } \\
\mathbf{2 . 9 0}\end{array}$ & $\begin{array}{c}\text { RMSEA } \\
\leq .08\end{array}$ \\
\hline $\mathbf{1}$ Tükenmişlik (TUK) & 150,8 & 57 & 2,6 & 0,90 & 0,84 & 0,92 & 0,90 & 0,91 & 0,07 \\
\hline $\mathbf{2}$ Kişi Örgüt Uyumu (KÖU) & 143,8 & 50 & 2,8 & 0,90 & 0,85 & 0,92 & 0,90 & 0,90 & 0,08 \\
\hline $\mathbf{3}$ işten Ayrılma Niyeti (iAN) & 1,2 & 2 & 0,6 & 0,99 & 0,98 & 0,99 & 0,99 & 0,99 & 0,00 \\
\hline
\end{tabular}

Not: Uyum iyiliği değer aralıkları "kabul edilebilir standartlara" göre düzenlenmiştir.

\subsection{Güvenilirlik Analizi}

Kullanılan ölçeklerin içsel tutarlılıklarını belirlemek üzere Cronbach's Alpha yöntemi ile güvenilirlik analizi yapılmıştır. Duygusal tükenme, duyarsızlaşma, kişisel başarı, kişi-örgüt uyumu ve işten ayrılma niyeti ölçeklerine yönelik Cronbach's Alfa değerleri sırasıyla; $\alpha=0,80, \alpha=0,84, \alpha=0,84, \alpha=0,88, \alpha=0,86^{\prime}$ 'dır. Alfa değerlerine göre içsel tutarlılıklar güvenilir $(\alpha>0,70)$ düzeydedir (Nunnaly, 1978).

\subsection{Korelasyon Analizi}

Sağlık sektörü çalışanlarının tükenmişlik düzeylerinin işten ayrılma niyetine etkisini ve kişi-örgüt uyumunun aracılık rolünü belirlemeye yönelik olan bu araştırmada değişkenlere ilişkin elde edilen verilerin ortalamaları, standart sapmaları ve aralarındaki korelasyonlara bakılmıştır. Bulgular Tablo 3'de sunulmuştur. Analizin üçüncü aşamasında Baron ve Kenny (1986) tarafından önerilen üç aşamalı hiyerarşik regresyon analizi ile aracılık etkisi araştırımıştır. 
Sağlık Sektörü Çalışanlarında Tükenmişlik Duygusunun İşten Ayrılma Niyetine Etkisi: Kişi - Örgüt Uyumunun Aracılık Rolü

Tablo 3. Ortalama, S. Sapma ve Korelasyon Değerleri

\begin{tabular}{|c|l|c|c|c|c|c|c|c|}
\hline \multicolumn{2}{|c|}{ Değişkenler } & Ort. & S.S. & $\mathbf{1}$ & $\mathbf{2}$ & $\mathbf{3}$ & $\mathbf{4}$ & $\mathbf{5}$ \\
\hline $\mathbf{1}$ & Duygusal Tükenme (DT) & 2,7 & 0,92 & 1 & & & & \\
\hline $\mathbf{2}$ & Duyarsızlaşma (DYR) & 2,6 & 0,74 & $0,77^{* *}$ & 1 & & & \\
\hline $\mathbf{3}$ & Kişisel Başarıda Azalma (KBA) & 2,9 & 0,85 & $0,71^{* *}$ & $0,67^{* *}$ & 1 & & \\
\hline $\mathbf{4}$ & Kişi Örgüt Uyumu (KÖU) & 3,7 & 0,79 & $-0,59^{* *}$ & $-0,62^{* *}$ & $-0,071^{* *}$ & 1 & \\
\hline $\mathbf{5}$ & İşten Ayrılma Niyeti (IAN) & 2,8 & 0,64 & $0,63^{* *}$ & $0,54^{* *}$ & $0,68^{* *}$ & $-0,70^{* *}$ & 1 \\
\hline
\end{tabular}

Araştırma sonucunda elde edilen verilere SPSS ve AMOS programında analizler yapılmıştır. Tablo 3'de de görüldüğü gibi araştırmaya konu edilen tüm bağımlı ve bağımsız değişkenler arasında anlamlı ilişkiler bulunmaktadır. Bu nedenle değişkenler arasında önemli etkiler öngörülebilmektedir. Analiz kapsamında modelde çoklu doğrusal bağlantı sorunu olup olmadığını belirlemek maksadıyla doğrudaşlığa (collinearity) da bakılmıştır. Elde edilen tolerans ve VIF değerleri bağımsız değişkenler arası çoklu bağlantı olmadığını doğrulayan sonuçlar vermiş̧ir (Tolerans $>0,2, \mathrm{VIF}<10$ ).

Bu kapsamda aracılık etkilerini araştırmak üzere Baron ve Kenny (1986) tarafından önerilen üç aşamalı hiyerarşik regresyon analizi aracılığıyla kurgulanan hipotezler test edilmiştir.

Tükenmişliğin üç boyutu olan duygusal tükenme, duyarsızlaşma ve kişisel başarıda azalmanın sağılı çalışanlarının işten ayrılma niyetine etkisini ve bu etkide kişi-örgüt uyumunun aracılık rolünü belirlemeye yönelik olan bu araştırmada, hipotezleri test etmek maksadıyla hiyerarşik regresyon analizleri yapılmıştır. Aracılık testine ilişkin bulgular Tablo 4, 5 ve 6' da verilmektedir.

Ilk aşama olarak aracılık testi kapsamında tükenmişlik bağımsız değişkeninin ilk boyutu olan duygusal tükenme ile işten ayrıma niyeti arasındaki ilişkiler araştırılmıştır. Söz konusu aşamanın ilk adımında DT’nin IAN'ni $(\beta=0,63, p<0,01)$ anlamlı olarak etkilediği belirlenmiştir. Aşamanın ikinci adımında DT'nin aracılığı araştırılan KÖU'na olan etkisi incelenmiştir. Yapılan analiz neticesinde DT'nin KÖU'nu anlamlı ve negatif olarak etkilediği $(\beta=-0,9, p<0,01)$ tespit edilmiştir. Bu adımda aracılığı araştırılan KÖU'nun IAN'ne olan etkilerine de bakılarak rapor edilmiştir. KÖU'nun IAN'ni $(\beta=-0,70, p<0,01)$ anlamlı ve negatif olarak etkilediği tespit edilmiştir. Bu aşamanın son adımında ise DT ve aracılığı araştırılan KÖU birlikte analize dâhil edilmiş ve bağımlı değişken olan IAN üzerindeki etkilerine bakılmıştır. Bu analiz neticesinde DT'nin KöU ile birlikte analize dâhil edilmesiyle IAN üzerindeki etkisi devam etmiş ve azalmış $(\beta=0,50, p<0,01)$, kÖU'nun da IAN üzerindeki etkisi devam etmiştir $(\beta=-0,43, p<0,01)$. Bu şartların sağlanmış olması sebebiyle aracılık etkisini teyit etmek amacıyla Sobel testi yapılmış ve Sobel(z) anlamlı bulunmuştur $(z=6,7, p<0,01)$. Bu bulgu DT'nin IAN'ne etkisinde KÖU'nun kısmi aracılık rolü üstlendiğini göstermektedir. Bu bölüm analizleri sonucunda H1, H4, H7 ve aracılık hipotezi olan H8'in desteklendiği görülmektedir.

Aracılık testinin ikinci aşamasında tükenmişlik bağımsız değişkeninin ikinci alt boyutu olan duyarsızlaşma ile işten ayrıma niyeti arasındaki ilişkiler incelenmiştir. Söz konusu bu aşamanın ilk adımında DYR'nın IAN'ni $(\beta=0,54, p<0,01)$ anlamlı olarak etkilediği görülmüştür. Aşamanın ikinci adımında DYR' nın aracılığı araştıılan KÖU'na olan etkisi incelenmiştir. Analiz sonucunda DYR'nin KÖU'nu anlamlı ve negatif olarak etkilediği $(\beta=-0,62, p<0,01)$ bulgulanmıştır. Bu aşamanın son adımında ise DYR ve aracılığı araştırılan KÖU birlikte analize dahil edilmiş ve IAN üzerindeki etkilerine bakılmıştır. Bu analiz neticesinde DYR'nın KÖU ile birlikte analize sokulmasıyla İAN üzerindeki etkisi devam etmiş ve azalmış $(\beta=0,42, p<0,01)$, KÖU'nun da IAN üzerindeki etkisi devam etmiştir $(\beta=-0,38, p<0,01)$. Bu şartların sağlanmış olması sebebiyle aracılık etkisini teyit etmek amacıyla Sobel testi yapılmış ve Sobel(z) anlamlı bulunmuştur $(z=3,8, p<0,01)$. Bu bulgu DYR'nın IAN'ne etkisinde KÖU'nun kısmi aracılık rolü üstlendiğini göstermektedir. Bu bölüm analizleri sonucunda H2, H5 ve aracılık hipotezi olan H9'un desteklendiği görülmektedir.

Aracılık testinin son aşamasında tükenmişlik bağımsız değişkeninin üçüncü alt boyutu olan kişisel başarıda azalma ile işten ayrılma niyeti arasındaki ilişkiler incelenmiştir. Söz konusu bu aşamanın ilk adımında 
KBA'nın IAN'ni $(\beta=0,68, p<0,01)$ anlamlı olarak etkilediği tespit edilmiştir. Aşamanın ikinci adımında KBA'nın aracılığı araştırılan KÖU'na olan etkisi incelenmiştir. Yapılan analiz sonucunda KBA'nın KÖU'nu anlamlı ve negatif olarak etkilediği $(\beta=-0,71, p<0,01)$ tespit edilmiştir. Bu aşamanın son adımında ise KBA ve aracılığı araştıılan KÖU birlikte analize dahil edilmiş ve IAN üzerindeki etkilerine bakılmıştır. Bu analiz neticesinde KBA'nın KÖU ile birlikte analize dahil edilmesiyle IAN üzerindeki etkisi devam etmiş ve azalmış $(\beta=0,49$, $p<0,01)$, KÖU'nun da IAN üzerindeki etkisi devam etmiştir $(\beta=-0,40, p<0,01)$. Bu şartların sağlanmış olması sebebiyle aracılık etkisini teyit etmek amacıyla Sobel testi yapılmış ve Sobel(z) anlamlı bulunmuştur ( $z=5,2$, $p<0,01)$. Bu bulgu KBA'nın IAN'ne etkisinde KÖU'nun kısmi aracılık rolü üstlendiğini göstermektedir. Bu bölüm analizleri sonucunda $\mathrm{H3}, \mathrm{H} 6$ ve aracllık hipotezi olan $\mathrm{H} 10$ 'un desteklendiği görülmektedir. Tüm bu sonuçlardan hareketle, regresyon analizleri ile test edilen toplam 10 hipotezin tamamı destek bulmuştur.

Tablo 4. Aracılık Testi Sonuçları (DT-KÖU-IAN)

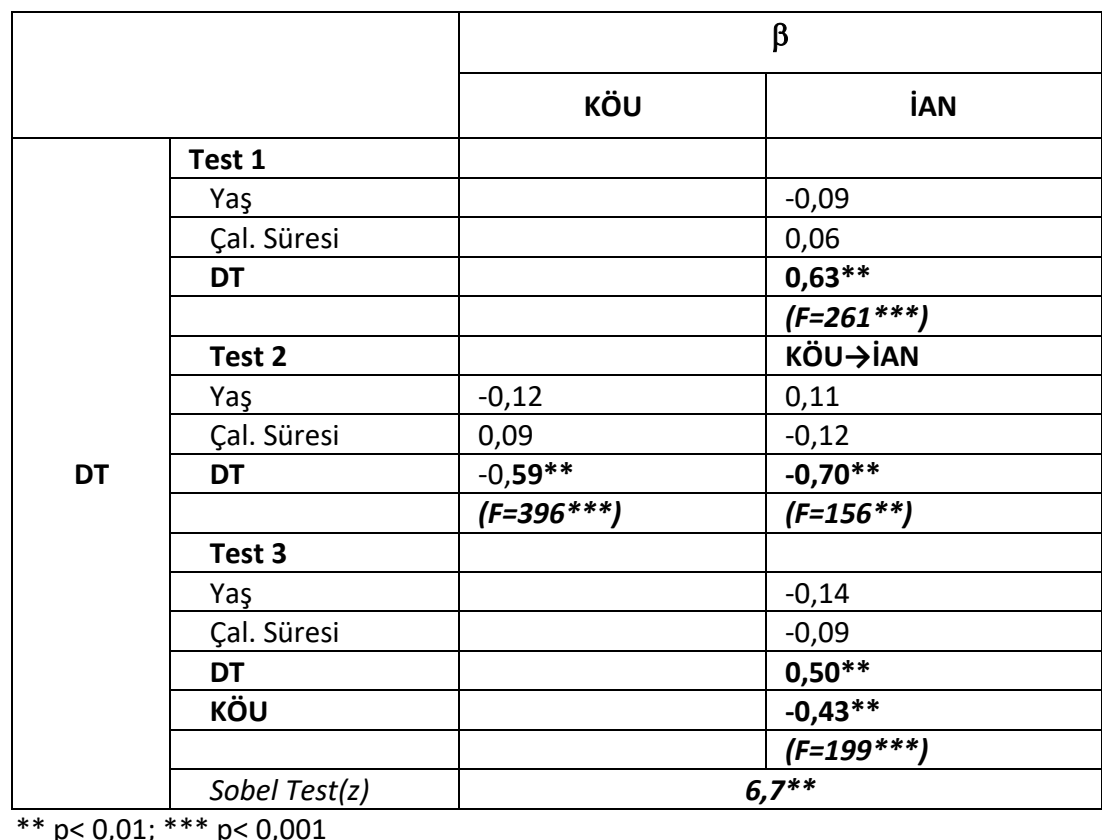

Tablo 5. Aracılık Testi Sonuçları (DYR-KÖU-IAN)

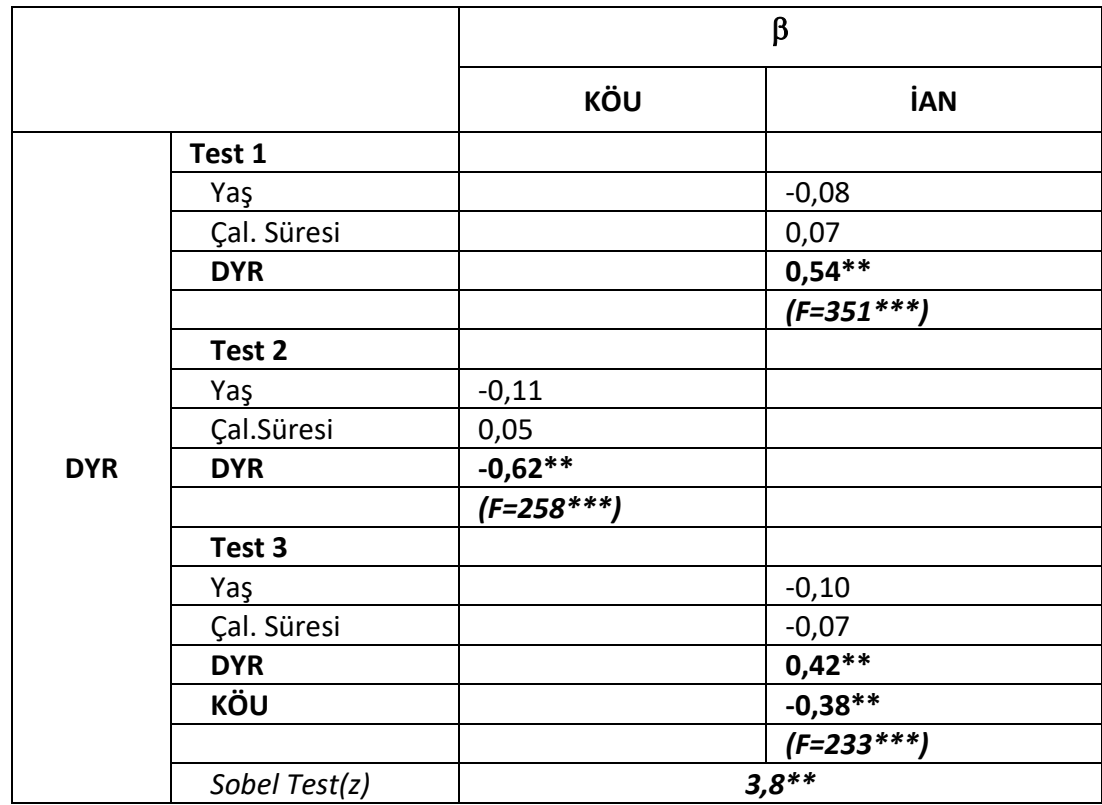

** $p<0,01 ; * * * p<0,001$ 
Tablo 6. Aracılık Testi Sonuçları (KBA-KÖU-IAN)

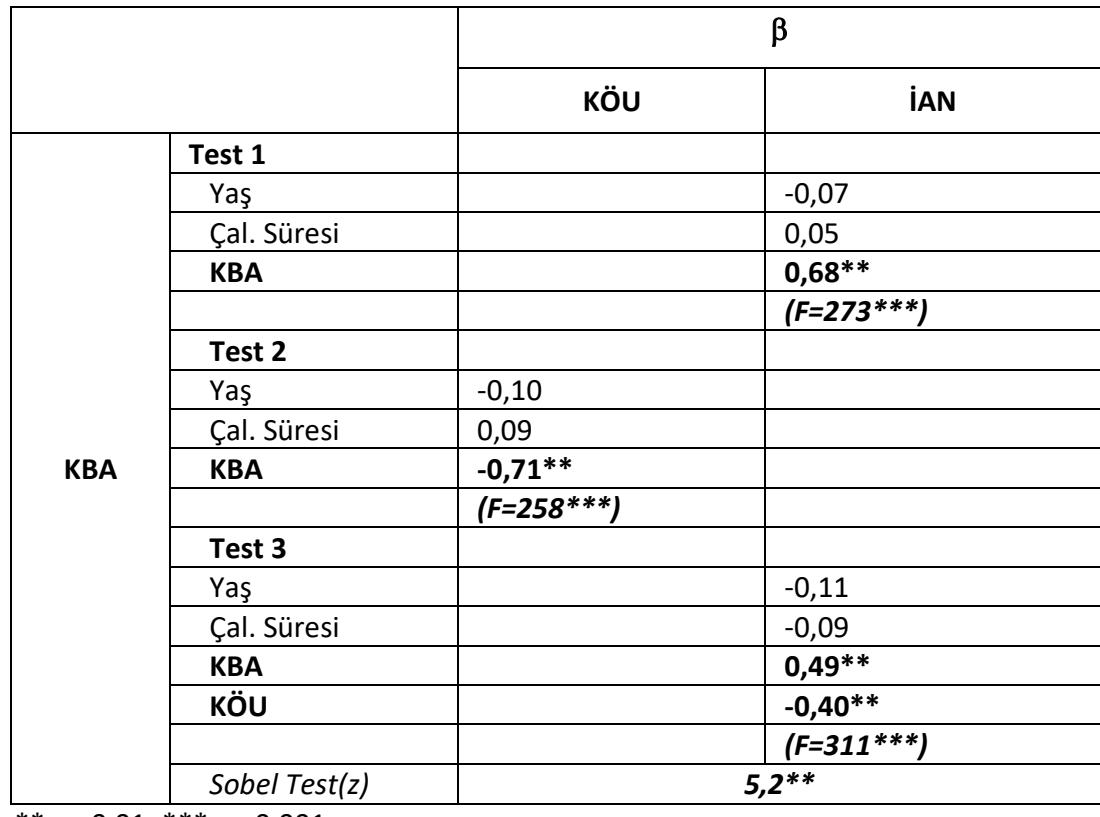

** $p<0,01 ; * * * p<0,001$

\section{Sonuç ve Tartışma}

Bu çalışmanın amacı, Sosyal Mübadele Teorisi (1964) ve Kişi-Örgüt Uyumu Teorisinden (1971) hareketle tükenmişlik duygusunun üç alt boyutu ile işten ayrılma niyeti ilişkisi ve bu ilişkide kişi-örgüt uyumunun aracılık rolünü tespit etmektir.

Araştırmada kullanılan tüm analizler neticesinde tükenmişlik duygusunun üç alt boyutunun (duygusal tükenme, duyarsızlaşma, kişisel başarıda azalma) işten ayrılma niyeti ile pozitif yönde ilişkili olduğu ve bu ilişkide kişi-örgüt uyumunun kısmi aracılık etkisine sahip olduğu tespit edilmiştir.

Korelasyon analizi sonucunda ortaya çıkan korelasyon katsayıları dikkate alındığında; 0.01 anlamlılık düzeyinde tükenmişliğin alt boyutlarından duygusal tükenme ve duyarsızlaşma ile kişi-örgüt uyumu arasında orta düzeyde, kişisel başarıda azalma alt boyutu ile kişi-örgüt uyumu arasında kuvvetli düzeyde anlamlı ve negatif yönlü bir ilişki olduğu tespit edilmiştir. Korelasyon analizi neticesinde elde edilen diğer bulgulara göre; tükenmişliğin tüm alt boyutları ile işten ayrılma niyeti arasında orta düzeyde anlamlı ve pozitif iliş̧iler olduğu; kişi-örgüt uyumu ile işten ayrılma niyeti arasında da yine orta düzeyde anlamlı ancak negatif ilişkiler olduğu tespit edilmiştir.

Yapılan regresyon analizi ile tükenmişlik, kişi-örgüt uyumu ve işten ayrılma niyeti arasındaki birliktelik ve neden-sonuç ilişkileri açıklanmaya çalışımış ve araştırma amacı doğrultusunda oluşturulan modelde öngörülen hipotezlerin doğrulukları test edilmeye çalışılmıştır. Sonuçlar tükenmişlik alt boyutlarının işten ayrılma niyeti üzerinde anlamlı ve pozitif etkilere sahip olduğunu; tükenmişlik alt boyutlarının kişi-örgüt uyumu üzerinde anlamlı ve negatif etkilere sahip olduğunu ve son olarak kişi-örgüt uyumunun işten ayrılma niyeti üzerinden anlamlı ve negatif etkilere sahip olduğunu göstermektedir.

Araştırma kapsamında yapılan analizler sonucunda sağlık sektörü çalışanlarının tükenmişlik duygusuna sahip oldukları ve bu duygunun yarattığı olumsuzlukla işten ayrılma niyeti sergiledikleri belirlenmiştir. Söz konusu bu sonuçlar önceki çalışmalarda elde edilen bulguları destekler niteliktedir (Onay ve Kılcı, 2011; Deniz vd., 2015; Ismaıl, 2015; Andrew, 2018; Santosa vd., 2018) Bunun yanı sıra çalışmanın diğer bir sonucu olarak ortaya çıkan, kişi-örgüt uyumunun bu iki değişken arasında kısmi aracılık rolüne sahip olması, çalışanların değerleri ve beklentileri ile örgüt değerleri arasındaki uyumsuzluğun bu olumsuz duyguları tetikleyebileceği yönünde bir görüş oluşturmaktadır. Bu sonuçlar da daha önce yapılmış ve literatüre 
kazandırılmış olan çalışmalar ile uyum göstermiştir (Behram ve Dinç, 2014; Abzari vd., 2015; Nuansa vd., 2018).

Araştırma sonuçları çalışmanın kuramsal dayanağını teşkil eden Sosyal Mübadele Teorisi (1964) ve Kişi-Örgüt Uyumu Teorisi (1971) ile örtüşmektedir. Çalışmanın ilk kuramsal dayanağı olan Sosyal Mübadele Teorisine göre, çalışanlar örgütlerinden bir takım beklentiler içerisindedir. Bu beklentiler içerisinde sayılabileceklerden bazıları saygı görme, takdir edilme, dikkate alınma, fikirlerine önem verilmedir. Çalışanlar söz konusu beklentilerinin karşılandığı oranda örgüt için çaba sarf etme eğilimi içerisinde olmaktadır. Bu karşııklı ilişkinin bir gereğidir. Ancak, fikirleri önemsenmeyen, dikkate alınmayan kısacası maddi ve manevi beklentileri karşılanmayan çalışanlar, örgütle aralarında kurulan karşııklı ilişkinin bağını hissedemeyecek hale gelerek değersizlik hissi ile ruhen ve bedenen yaptıkları işe ve örgütlerine karşı gösterdikleri çabayı azaltarak örgütte kalma niyetlerini azaltabilirler. Çalışmanın dayanak aldığı diğer teori olan Kişi-Örgüt Teorisine göre, bireyin davranışlarının temelinde yatan, kendini ve başkalarını tanımakta ve ilişkilerinde kullanmakta olduğu değerlerinin, örgüt değerleri ile uyumlu olması gerekmektedir. Çalışanlar bu değer beklentileri doğrultusunda örgüt için yaptıkları çabayı arttııp azaltma davranışı sergileyeceklerdir. Bu sebeple bu uyumun olmaması ya da var olan uyumun bozulması çalışanları tükenmişlik duygusuna sürükleyerek örgütle bağlarını koparmalarına sebebiyet verecektir. Çünkü çalışanların işten ayrılma niyeti sergilemelerinin örgütle olan benzer özellikleri ve değerleri neticesinde oluşan uyumu önemsemeye bağlı olduğu söylenebilir. Yapılan araştırmalar ve kuramdan yola çıkılarak oluşturulmuş olan bilgiler doğrultusunda kurgulanan araştırmamızın sonuçları kuram ve görgül araştırmaları destekler niteliktedir.

Buna bağlı olarak araştırma sonuçları doğrultusunda konu ile ilgilenecek uygulayıcılar ve araştırmacılar için bir takım önerilerde bulunmak mümkündür. Öncelikle bireylerin kendilerini tanıma yolunda kişisel değerlerini bilmeleri, bu değerlere uygun işler ve kurumlarda yer almaları son derece önemli bir konu olarak karşımıza çıkmaktadır. Örgütlerin işe alım süreçlerinde işin gerektirdiği nitelikleri doğru bir şekilde belirlemeleri ve kişi-iş, kişi-örgüt uyumunu ön plana alarak personel seçimleri yapmaları gerekmektedir. Özellikle sağılı sektörünün diğer sektörlerden karmaşık bir yapıya sahip olması ve yapılan işin verilen hizmetin telafisi olmayan durumlara yol açabilecek olması bu sektörde çalışan kişiler üzerinde baskı yarattığı unutulmamalıdır. Özellikle özel finansmanla finanse edilen sağlık kurumlarının bu doğrultuda çalışma koşullarını iyileştirerek çalışanlarının stres seviyelerini azaltacak tedbirler almaları önerilebilir.

Bu araştırmanın bazı sınırlılıkları bulunmaktadır. Çalışmanın tek bir ilde, tek bir sektörde faaliyet gösteren işletmelerde yapılmış olması önemli bir kısıt olarak düşünülmektedir.

Çalışmanın boylamsal olmaması bir diğer kısıtıdır. Araştırmada söz konusu olan değişkenlerin zamanla değişime maruz kalabileceği göz önünde bulundurularak bulguların araştırmanın uygulandığı zaman ve dönemle sınırlı olduğu bilinmelidir. Çalışma sonuçlarının katılımcıların verdikleri yanıtlarla ve bireysel algılarına dayalı olduğu göz önünde bulundurulmalıdır. Gelecek dönem araştırmalarında farklı örgüt kültürüne sahip sektörlere odaklanmak araştırma sonuçlarını farklılaştırabilir.

\section{Son Notlar}

* Bu çalışma, 02-03 Kasım 2018 tarihlerinde Isparta Süleyman Demirel Üniversitesi'nde düzenlenmiş olan “6. Örgütsel Davranış Kongresi'nde" sunulmuş genişletilmiş özetin revize edilmiş halidir.

\section{Kaynaklar}

Abzari, M., Kabiripour, V., \& Saeidi, A. (2015). The effect of business ethical values on turnover intention: Mediating role of person-organization fit dimensions. The case of Iranian teachers in public school. Academic Journal of Economic Studies, 1(1), 65-81.

Aghdasi, M. T. (2014). The relationship between perfectionism and burnout in Junior-Elite Athletes. International Journal of Science Culture and Sport, 2(1), 27-39. 
Sağlık Sektörü Çalışanlarında Tükenmişlik Duygusunun İşten Ayrılma Niyetine Etkisi: Kişi - Örgüt Uyumunun Aracılık Rolü

Akbaş, T. T. (2011). Algılanan kişi-örgüt uyumunun örgütsel vatandaşlık davranışları üzerindeki etkisi: Görgül bir araştırma. Çanakkale Onsekiz Mart Üniversitesi i.i.B.F. Yönetim Bilimleri Dergisi, 9(1), 53-81.

Altay, B., Gönener, D., \& Demirkıran, C. (2010). Bir üniversite hastanesinde çalışan hemşirelerin tükenmişlik düzeyleri ve aile desteğinin etkisi. Fırat Tıp Dergisi, 15(1), 10-16.

Ardıç, K., \& Polatçı, S. (2009). Tükenmişlik sendromu ve madalyonun öbür yüzü: İşle bütünleşme. Erciyes Üniversitesi iktisadi ve Idari Bilimler Fakültesi Dergisi, 32, 21-46.

Aslan, Z. (2014). İşgörenlerin tükenmişlik düzeylerinin işten ayrılma niyeti üzerine etkisi: İstanbul'daki seyahat acentalarında bir araştırma. Nevşehir Hacı Bektaş Veli Üniversitesi Sosyal Bilimler Enstitüsü Dergisi, 3, 19-40.

Azharudeen, N. T., \& Andrew, A. (2018). Emotional exhaustion and employee turnover intention. International Journal of Research, 5(1), 227-240.

Babakuş, E., Yavaş, U., \& Ashill, N. J. (2011). Service worker burnout and turnover intentions: Roles of person-job fit, servant leadership and customer orientation. Services Marketing Quarterly, 32, 17-31.

Behram K., N., \& Dinç, E. (2014). Algılanan kişi-örgüt uyumunun kişilerarası çatışma ve işten ayrılma niyeti üzerine etkisi. Aksaray Üniversitesi Iktisadi ve Idari Bilimler Fakültesi Dergisi, 7(1), 115-124.

Billsberry, J., Ambrosini, V., Moss-Jones, J., \& Marsh, P. (2005). Some suggestions for mapping organizational members' sense of fit. J. Bus Psychol, 19(4), 555-570.

Cable, D. M., \& DeRue, D. S. (2002). The convergent and discriminant validity of subjective fit perceptions. Journal of Applied Psychology, 87, 875-884.

Cable, D. M., \& Parsons, C. R. (2001). Person-organization fit, job choice decisions, and organizational entry. Organizational Behavior and HumanDecision Processes, 54, 1-23.

Cuskelly, G., \& Boag, A. (2001). Organizational commitment as a predictor of committee member turnover among volunteer sport administrators: Results of a time-lagged study. Sport Management Review. 4(1), 65-88.

Çam, O. (1998). Tükenmişlik üzerine bir değerlendirme. Ege Üniversitesi Hemşirelik Yüksek Okulu Dergisi, 14(1), 81-93.

Çetinkaya, A. Ş., \& Kurnaz, G. (2017). Kişi-iş uyumunun performans değerlemeye etkisi: Konya tekstil işletmeleri araştırması. BMIJ, 5(3), 747-764.

Deniz, N., Noyan, A., \& Ertosun, Ö. G. (2015). Linking person-job fit to job stress: The mediating effect of perceived person-organization fit. Procedia- Social and Behavioral Sciences,207, 369-376.

Dursun, S., Kaya, U., \& İştar, E. (2015). Kişilik- iş uyumunun duygusal tükenmişlik ile iş ve yaşam doyumu üzerindeki etkisi: Muhasebe meslek mensupları üzerinde bir uygulama. KTU SBE Sosyal Bilimler Dergisi,9, 55-69.

Ergin, C. (1992). Doktor ve hemşirelerde tükenmişlik ve Maslach tükenmişlik ölçeğinin uyarlanması. 7. Ulusal Psikoloji Kongresi Bilimsel Çalışmaları, 22-25.

Farooqui, S., \& Nagendra, A. (2014). The impact of person organization fit on job satisfaction and performance of the employees. Procedia- Economics and Finance, 11, 122-129.

Garden, A. M. (1987). Depersonalisation, a valid dimension of burnout? Human Relations, 40, 545-560.

Haran, S., Devrimci, Ö. H., Ölmez, Ş., \& Sayıl, I. (1998). Ankara Üniversitesi Tıp Fakültesi Hastaneleri ve Ankara Numune Hastanesinde Çalışan Doktor ve Hemşirelerde Tükenmişlik Düzeyleri. Kriz Dergisi, 6(1), 75-84.

Ismall, H. (2015). Job insecurity, burnout, intention to quit. International Journal of Academic Research in Business and Social Sciences, 5(4), 310-324.

Johnsrud, L., \& Rosser, V. (2002). Faculty members' morale and their intention to leave: A multilevel explanation. Journal of Higher Education, 73(4), 518-542.

Lambert, E. G. (2006). I want to leave: A test of a model of turnover intent among correctional staff. Applied Psychology in Criminal Justice, 2(1), 57-83.

Makraiova, J., Pokorna, E., \& Woolliscroft, P. (2014). Person-organization fit in the context of cultural learning. Procedia Engineering, 69, 712-719.

Maslach, C., (1976). Burned-out. Human Behavior, 5, 16-22.

Maslach, C., Jackson, S. E. (1981). Manual of Maslach burnout inventory (2th ed.). California: Consulting Psychologists Press.

Maslach, C., Wilmar, B. S., \& Leiter, MP. (2001). Job burnout. Annual Reviews Psychology, 52(1), 397-422.

Meisler, G. (2013). Empirical exploration of the relationship between emotional intelligence, perceived organizational justice and turnover intentions. Employee Relations, 35(4), 441-455. 
Nuansa, R., Thatok, A., \& Siti, N. (2018). The role of organizational commitment mediation on the effect personorganization fit and job satisfaction to turnover intention. RJOAS, 2(74), 33-40.

Onay, M., \& Kılcı, S. (2011). İş stresi ve tükenmişlik duygusunun işten ayrılma niyeti üzerine etkileri: Garsonlar ve aşçıbaşılar. Organizasyon ve Yönetim Bilimleri Dergisi, 3(2), 363-372.

Özçelik, G., \& Afacan Fındıklı, M. (2014). The relationship between internal branding and organizational citizenship behaviour: The mediating role of person-organization fit. Procedia-Social and Behavioral Sciences, 150, 11201128.

Özgüven, H. D., Haran S. (2000). Tükenme. (İçinde) Kriz ve Krize Müdahale. I. Sayıl (Ed.), Ankara Üniversitesi Psikiyatrik Kriz Uygulama ve Araştırma Merkezi Yayınları, Ankara: 199-214.

Santoso, A. L., Sitompul, S. A., \& Budiatmanto, A. (2018). Burnout, organizational commitment and turnover intention. Journal of Business and Retail Management Research, 13(1), 62-69.

Simha, A., Elloy, D. F., \& Huang, H.C. (2014). The moderated relationship between job burnout and organizational cynicism. Management Decision, 52(3), 482-504.

Sousa, J. M., \& Porto, J. B. (2015). Happiness at work: Organizational values and person-organization fit impact. Paideia, 25(61), 211-220.

Sousa-Poza, A., \& Henneberger, F. (2002). Analyzing job mobility with job turnover intentions: an international comparative study. Research Institute for Labour Economics and Labour Law. 82, 1-28.

Sökmen, A., \& Bıyık, Y. (2016). Örgütsel bağlılık, örgütsel özdeşleşme, kişi-örgüt uyumu ve iş tatmini ilişkisi: Bilişim uzmanlarına yönelik bir araştırma. Bilişim Teknolojileri Dergisi, 9(2), 221-227.

Storm, K., \& Rothmann, S. (2003). The relationship between burnout, personality traits and coping strategies in a corporate pharmaceutical group. SA Journal of Industrial Psychology, 29(4), 35-42.

Takawira, N., Coetzee, M., \& Schreuder, D. (2014). Job embeddedness, work engagement and turnover intention of staff in a higher education institution: An exploratory study. SA Journal of Human Resource Management, 12(1), 110.

Tett, R. P. \& Meyer, J. P. (1993). Job satisfaction, organizational commitment, turnover intention and turnover: Path analyses based on meta-analytic findings. Personal Psychology, 46, 259-293.

Thakre, N. (2015). Organizational commitment and turnover intention in BPO-Ites and retail sector employees. Journal of Psychosocial Research, 10(1), 89-98.

Tong, J., Wang, L., \& Peng, K. (2015). From person-environment misfit to job burnout: Theoretical extensions. Journal of Managerial Psychology, 30(2), 169-182.

Tosun, N., \& Ulusoy, H. (2017). The relationship of organizational commitment, job satisfaction and burnout on physicians and nurses. Journal of Economics and Management, 28(2), 90-111.

Turunç, Ö. (2015). Stratejik yönetim örgütsel performans ilişkisinde kişi-örgüt uyumunun rolü. Uluslararası iktisadi ve idari Bilimler Dergisi, 1(1), 16-30.

Uluköy, M. (2014). Sağlık çalışanlarının örgütsel adalet algısı ile tükenmişlik duyguları arasındaki ilişki: Bir Uygulama. Dumlupınar Üniversitesi Sosyal Bilimler Dergisi, 39, 213-226.

Vilela, B. B., Varela Gonzalez, J. A., \& Ferrin, F. F. (2008). Person- organization fit, OCB and performance appraisal: Evidence from matched supervisor-sales-person data set in a Spanish context. Industrial Marketing Management, 37, 1005-1019.

Wei, Y. C. (2012). Person-organization fit and organizational citizenship behavior: Time perspective. Journal of Management and Organization, 18(6), 833-844. 
This Page Intentionally Left Blank 